\title{
What Competitive Strategies Way forward the Regional Competitiveness? A Comparative Economic Approach to Sri Lankan Tourism
}

\author{
Imali N. Fernando ${ }^{1}$ \\ ${ }^{1}$ Faculty of Management, Uva Wellassa University of Sri Lanka, Sri Lanka \\ Correspondence: Imali N. Fernando, Faculty of Management, Uva Wellassa University of Sri Lanka, Sri Lanka. \\ E-mail: imalif@uwu.ac.lk
}

Received: September 12, 2014

Accepted: February 27, 2015

Online Published: March 27, 2015

doi:10.5539/ijbm.v10n4p178

URL: http://dx.doi.org/10.5539/ijbm.v10n4p178

\begin{abstract}
In present dynamic era, Tourism considered as one of the key service sector industry as the competitive advantage is not a natural phenomenon but an innovation driven competitive strategies combined with the aspirations of visitors. Destination's enriched resources not determining the share of tourism, but the way they manage and integrate with other competencies to create the competitive advantage. Hence the main research question developed as, what competitive strategies way forward the regional competitiveness in Sri Lankan tourism and primary objective developed as to ascertain the elements of a new paradigm that would help Sri Lanka to become a competitive tourism destination within regional tourism market. For a panel of seven destinations, Econometric modeling employed to identify the variables that impact on tourism destination competitiveness with selected set of rival destinations. Model based on a utility function embedded in rational choice theory has developed and to discern whether the panel data set was stationary, panel unit root test has performed. Two variables, development and investment was not stationary, model slightly revised to log values and Generalized Leased Squares (GLS) have used to test the model. Results indicate, after removal of lagged value, all the variables were significant except for the investment. Results signals the vital role of the government policies to enhance the ability on overcoming distortions and enabling price to send signals to potential markets as with restoring price informative power of particular tourism destinations. The destinations could attract 'tourism product' by considering more to preferences and tastes in a creative and innovative approach and consistent way as by adjusting and implementing strategies on non-price competition. Three competitive strategies have proposed (a) to shift management policies and strategies on real spending per arrival or tourism spending per tourist, (b) applying Non-price competitive strategies and (c) enhancing the national wealth of tourism destination from creating and well managing the destination resources
\end{abstract}

Keywords: competitiveness, non-price strategies, Sri Lankan tourism

\section{Introduction}

In present scenario, tourism is a major economic service among world; so on destinations no longer take passive approaches to underutilize the resources. Tourism is a sector that in naturally covered vast area with linkages in each direction as to provide tourism experience to the tourists, by visitation process. Naturally there are many stakeholders involved, both directly and indirectly, each stakeholder is important as the "perceived satisfaction" create competitiveness, by making re-visits to particular tourism destination. It further increase its market share, tourism volume by number of visitors, re-visits, tourists incomes generating as their expenses on locally, value to local services and airlines and in long run, increase the quality of life standards among residents. Competitive tourism destination should be ensuring on a higher level than its rivals/ competitors as by (a) Satisfaction of guests, (b) Profit for tourism-oriented industries among significant tourism growth in particular area, (c) High in standards of living of local community and (d) Protection / sustainability of the environment. It's evident that only few attentions made in past to analyze and understand the "experience provided by tourism", because more concerned on to attract tourists to the destination in high volumes, simply neglecting the core tourism product. Although tourism sector highlights its importance on the developing economies, still its less-focus on value-delivery focusing innovative practices and produces by focusing mostly on natural resources endowments on traditional tourism. In past years Sri Lankan tourism was in a lag behind position because of the civil war 
since 1979, cause to lose its competitiveness focus, as well as fails to model what strategies applicable to this treasured island to be a competitive destination. Presently tourism arrivals and receipts are in a weak position compared to world averages and to those among rival destinations in Asia. As a country that put forwarding its visionary strategies to be a competitive destination in 2016 and to move from low-value market cluster of beach tourism to high-valued clusters, its vital to model the tourism by identifying the significant aspects on competitiveness.

Sri Lanka is a famous tourism destination for "Sun and Sand" because of island's exotic beaches. The country is in a position to think beyond traditional boundaries, by tapping into new market segments, with new thematic tourism clusters, as to become a competitive tourism destination. Competitive advantage in tourism is not a natural phenomenon but an innovation driven competitive focus combined the aspirations of visitors specially focusing experiences. The stock of enriched resources of Sri Lanka will not determine the tourism market share, but how they manage and integrate other competencies to generate the destination competitive advantage. Sri Lanka is an island inherited with vast natural resources and rich cultural heritage, as comparative advantage, but lack of competitiveness (81 place in 2011 and 78 place in 2009 among 139 countries, World Travel and Tourism Competitiveness Report, 2011) because of competitive advantage focus on innovation driven strategies. It is justifiable as developing country tourism destinations are characterized with an abundance of natural or inherited resources, but not be able to create significant portion of economic gains from the tourism.

\subsection{Research Questions}

The main research question developed as, "What competitive strategies way forward the regional competitiveness in Sri Lankan tourism?"

The sub research questions have been developed as;

$>$ What factors economically affect to enhance the regional competitiveness in tourism?

$>$ What policy recommendations and innovation driven strategies could implement on to contribute to the national economy?

\subsection{Research Objectives}

The primary objective of the study is defined as to; Ascertain the elements of a novel paradigm that would help Sri Lanka to become a competitive tourism destination within regional tourism market

The secondary objectives developed as;

$>$ To identify the competitive strategies focused on innovation, as to way forward Sri Lanka as a top class tourism destination

To provide a better set of suggestions and polices to success on tourism cluster

\section{Material Studied}

Over the past two decades, eminent scholars and economists have enlightened the theoretical base as to develop an approach to address the issue of competiveness. The present stage in the developing a theory for destination competiveness have achieved a significant growth as to identify the significant elements in a tourism destination, as the focus of research move towards assessing relative importance of attributes or significant elements on competitiveness. As in the decade of 90's, Crouch and Ritchie developed a conceptual model that to tailored distinctive characteristics of destination competitiveness, by combining the attributes in Porter's Diamond model Their model recognizes that destination competitiveness based upon destinations' resource endowments (comparative advantages) and capacity to deploy resources (competitive advantage) and acknowledge the impact of global macro-environmental forces and competitive micro-environmental circumstances, (Crouch \& Ritchie, 1995, 1999), Ritchie and Crouch (2000). Modern tourism is "experience" oriented, based on competitiveness rather than comparative scenic beauty in a destination. Different scholars view competitiveness in different ways (Bobirca et al., 2006). Omerzel (2006) explains, in the paradox of tourism, globalization cause to form dramatic numbers of destinations all over the globe. Economists have emphasized on economic characteristics specific to the price and country level, while management focusing on the characteristics specific to firms, and sociologists and Politians' covering a vast area such as the characteristics related to the society, culture and politics that contributing to the competitiveness in broader sense. This is the reason that competitiveness could be measured in different perspectives, no special way as a rule of thumb. There can see a transition from mass tourism to a "new age of tourism' that called as, management quality, tailor-made approach to specific attitudes, needs and wants of tourists (Cracolici et al., 2006). Nordin (2003) mentioned that Porter illustrated the location is no longer has no competitive advantage, as such open global markets, rapid enhancements on transportation and 
communication should overcome that competitive advantage given by the 'location'. Competitiveness is a new challenge for the tourism sector, as competition for larger share in tourism pie, in globally emerging. As Omerzel (2006), comparative advantage and competitive advantage of tourism seems to be much more important to an economy. Comparative advantages include climate, scenery, forests, waterways and wild life as related with primary tourism supply. But competitive advantage means, infrastructure workforce skills and knowhow, policies of government etc. They pave way for the competitiveness of a given destination. Wares et al. (2008) further explains competitiveness in different levels, as in firm level and national level. In firm level, the firm is competitive if it can compete successfully with rivals and in national level, competitiveness reflects the ability of a country to use its resources in a way that increase the socio economic development of people. The focus on tourism industry has shifted from simply attracting more tourists to increase the competitiveness of the destinations. As innovations has been long recognized as a key factor in competitive advantage, Walsh et al. (2010) explain this is a necessary condition but not sufficient and highlights the importance of other aspects as in line with gaining competitiveness for tourism industry.

Inman et al. (2002) argued the abundance of natural resources of many nations move for develop their competitive skills, as a nation's prosperity depends on the level of productivity and competitiveness of business and industries. Loss of competitiveness is a significant challenge nowadays for all tourism stakeholders. There is a "universal view" among comparing destinations in competitiveness with each other also its vital to compare several types of tourist destinations, like cities and resorts (Enright et al., 2005). Crouch and Ritchie (1995), explains tourism development policies and plans, organizational structures and the marketing strategies drive destinations more to competition, but it should focus more on what that makes a tourism destination competitive. Yuksel et al. (2000) explain as if there is a shortcoming at a most critical interface such as tourist contact front-line employee in a given destination resort, all other factors are insignificant. Even if destination has a best strategic focus, best scenery or adventure experiences in resort, those things diminish just one second of first impression on hospitality, that highlight the importance on destination management in tourism competitiveness.

There cannot observe any single or specific/unique set of destination competiveness measures that can apply to every destination, Omerzel (2006), Kim and Dwyer (2003), Fernando and Long (2012), Fernando (2013). Generally it includes two types as in objective measures such as number of visitors, market share, employment, tourism income and subjective measures as climate, environment and scenic beauty, attractiveness, heritage and cultural image (Omerzel, 2006). Armenski et al. (2011) pointed out, the complexity of the term "competitiveness" is become apparent that attempt to define and measure, and there can see different models both objective and /or subjective measures created. As pointed out by the scholars, developing country arena, competitive strategies embedded with innovations will way forward towards economic prosperity, (Fernando \& Long, 2012; Fernando, 2013).

\section{Research Methods}

secondary data from various tourism statistics, as WTO, WTTC, UN statistics, World Bank statistics, statistics in Sri Lanka have used, as the rival destination have selected according to the survey done by the researcher in Sri Lanka during 2012 March-September period. Econometrics methods (panel unit root test, fixed effect modeling) have used to co-op with the objective to explore the competitiveness in Sri Lanka in the regional tourism

Econometric modeling has used to identify the variables that impact on tourism destination competitiveness with selected set of rival destinations. A model based on a utility function embedded in rational choice theory has developed. Main assumptions that a consumed goods provide a higher utility than a unconsumed goods and considered that on seven tourism destinations on the study.

The tourism utility function developed as $\mathbf{U}(\mathbf{X}, \mathbf{R})$, as " $\mathbf{X}$ " represents goods purchased by the consumer in the market combined with "R" no-market resources, and "p" denotes the vector of market prices corresponding to "X". Hence as assumptions has been drawn from utility functions and " $\mathbf{R}$ " considered as a conventional good in the market. The expenditure (cost) function as:

$C(p, R, u)^{*}=\min \{x p \mid U(X, R)=u\}$ where $u^{*}$ represents the reference level of utility

"C" express the minimum cost level that achieving the utility on " $\mathbf{R}$ " resources level, and further assumed the costs associated with tourism investments as in minimum required for a destination, as the investments on transportation and telecommunication, general infrastructure, safety and education level the demand for tourism. As Croes (2010) pointed out that other tourism resources as water, land, buildings etc. have little impact as in the perspective of tourists. The model developed and variables defined as accordingly; the dependent variable (DV) is the tourists receipts per arrivals in US\$, denoted as VALUE, as it reflects the real value per tourist, per the 
economy. As price movements interpret with the higher and lower tourism expenditures and it's associated with the TALC factor mentioned by Croes (2010) as, destinations with lower end tourists might have assigned with a huge externality cost associated for the congested areas, pollution (air, water, noise etc.), transportation conditions and further it affects to minimize the destination carrying capacity. It mentions as low-spending tourist enjoying less value from destination and scholar mentions that the possibility associated with the destination to grab comparably higher value to economy from high priced products and services than increasing the tourists' arrivals. The model is defined as;

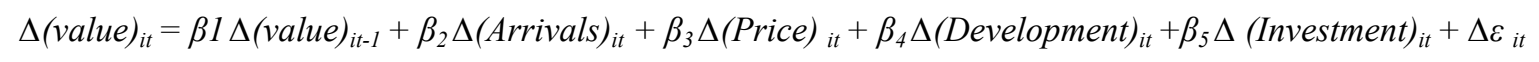

Where "i" denotes the destination and from $\mathrm{i}=1,2 \ldots 7$ and;

"t" denotes the year, from $\mathrm{t}=2002,2003 \ldots .2010$.

value it denotes the economic value that is generated by the destination $i$ during the year $t$, and defined as rate of growth of the consumed value of the tourists or in simply, the changing rate of real tourism spending per arrivals. Arrivals refers to visits of international tourists in year $t$ of $i$ destination. Further a proxy assigned to the cost. price denotes to $i$ destinations relative price, and as its relative nature calculated as a ratio on total receipts per each $i^{\text {th }}$ destination's portion in year $t$. the development denoted by Gross Domestic Product (GDP) per Capita and is taken as a proxy for the destinations' productivity as development level, as available technology and amenities as (security, infrastructure development etc.) are strongly correlated with economic development of destination $i$ on period $t$. for investments, it associated with investments and here taken as the service percentage from GDP as including tourism activities as well as other related services as a proxy. As the data on hotel capacity not available for the panel in time series, the service percentage from GDP has taken as a proxy, as for the investment on hospitality and Tourism, the other services as infrastructure and communication etc. also needed. Although Croes (2010) has taken the hotel capacity on each destination for the model developed as on small Island tourism competitiveness measures. The estimated coefficients are short-run elasticities and a panel regression analysis done in order to estimates the coefficients in model. The panel regression here referring to the panel data consists of observations on multiple phenomena for a time series, and according to the model there are 5 variables over 9 years and total 63 observations in panel. The variables have defined in table 1 below.

Table 1. Definition of variables

\begin{tabular}{ll}
\hline variable & definition \\
\hline $\begin{array}{l}\text { Value (Dependent variable } \\
\text { DV) }\end{array}$ & Rate of Growth of value consumed by visitor (changing rate of receipts per tourist arrivals) \\
$\begin{array}{l}\text { Value lagged } \\
\text { variables) }\end{array}$ & The arrivals per destination $i$ on time $t$ \\
$\begin{array}{l}\text { Arrivals } \\
\text { Price }\end{array}$ & $\begin{array}{l}\text { Price relative to the destinations total / ratio of real tourism receipts of destination } i \text { in year t, as to the total } \\
\text { receipts for the destination during year } t\end{array}$ \\
Development & $\begin{array}{l}\text { Development level of the destination and per capita GDP is taken as the proxy } \\
\text { Investment }\end{array}$ \\
& $\begin{array}{l}\text { Investment on tourism sector and has taken the service value added percentage of the GDP of destination } i \\
\text { on time } t\end{array}$ \\
\hline
\end{tabular}

Theoretical expectations of the model can be expressed as in; a) tourists arrivals are non linear function consists of initially positive effects although might indicate reverse or negative relationships also with the value. Simply it could take positive value or negative value in arrivals, b) tourists' value increase with the enhancements of the price and c) the value increases accordingly with tourism attractions increases. The error term $\left(\varepsilon_{\mathrm{it}}\right)$ represents the external shocks and the model assume shocks assigned with a constant variance and serially uncorrelated with the predictors on the regression.

\section{Results}

As to discern whether the panel data set was stationary or not, performed the panel unit root test for the data set (Levin, Lin and Chu unit root test). According to the results, two variables, development (GDPC) and investment was not stationary, then the model slightly changed by using log values of both as $\ln$ (development) and $\ln$ 
(investment) and taken the first difference of the two log variables, (table 2).

Table 2. Panel unit root test levin-lin and chu test

\begin{tabular}{llll}
\hline variable & sample & levels & Degree of integration \\
\hline Value & $2002-2010$ & $-1.8568^{*}$ & $\mathrm{I}(0)$ \\
Arrival & $2002-2010$ & $-4.2403^{* *}$ & $\mathrm{I}(0)$ \\
Price & $2002-2010$ & $-6.8745^{*}$ & $\mathrm{I}(0)$ \\
Development(GDPC) & $2002-2010$ & $-4.4824^{*}$ & $\mathrm{I}(0)$ or I $(1)$ \\
Investment & $2002-2010$ & $-7.9619^{*}$ & $\mathrm{I}(0)$ or I $(1)$ \\
\hline
\end{tabular}

- Test was carried by using STATA 11.2 package and the panel comprised of seven tourism destinations, Sri Lankan with 6 most competitive destinations according to the survey results.

- The table reports the adjusted statistics (t-star) for the Levin-Lin-Chu (2002) test at the $1 \% *$ and $5 \% * *$ significance level.

- An indication of * and (**) indicates rejection of the null hypothesis at the $1 \%$ and $5 \%$ significant levels respectively.

Then Generalized Leased Squares (GLS) have used as to test the model. Generalized least squares (GLS) is a technique using for linear regression model to estimate the unknown parameters. Although the GLS is applied in situations as the variances of the observations are heteroscedasticity, if it can observe a correlation of a certain degree among the observations. The estimation results of the test were provided in table 3 below.

Table 3. Results of the GLS model estimations

\section{Determinants of Tourism Competitiveness of Sri Lanka with Rival Destinations}

Cross-sectional time-series FGLS regression

Coefficients: generalized least squares

Panels: heteroskedastic with cross-sectional correlation

Correlation: common AR(1)

coefficient for all panels (-0.1271)

Estimated covariances $=28$

Number of obs $=56$

Estimated autocorrelations $=1$

Number of groups $=7$

Estimated coefficients $=6$

Time periods $=8$

Wald chi2 $(5)=24.40$

Prob $>$ chi $2=0.0002$

\begin{tabular}{lllllll}
\hline VALUE $\mid$ & Coef. & Std. Err. & $\mathbf{z}$ & $\mathbf{P}>|\mathbf{z}|$ & \multicolumn{2}{c}{ [95\% Conf. Interval] } \\
\hline VALUE L1. | & .107736 & .0755354 & 1.43 & 0.154 & -.0403106 & .2557825 \\
ARRIVALS $\mid$ & $-1.26 \mathrm{e}-07$ & $4.99 \mathrm{e}-08$ & -2.53 & 0.011 & $-2.24 \mathrm{e}-07$ & $-2.84 \mathrm{e}-08$ \\
PRICE $\mid$ & 17.41469 & 6.186415 & 2.81 & 0.005 & 5.289543 & 29.53984 \\
dlinv $\mid$ & -35.07446 & 9.379881 & -3.74 & 0.000 & -53.45869 & -16.69023 \\
dlgdp | & 8.3469 & 2.842885 & 2.94 & 0.003 & 2.774948 & 13.91885 \\
cons $\mid$ & 3.541637 & .9946031 & 3.56 & 0.000 & 1.59225 & 5.491023 \\
& & & & & & \\
\hline
\end{tabular}

- $\quad$ dependent variable $=($ value $)$ rate of difference in real spending per tourist (per capita) 
- $\quad$ Value L1 = Lagged value

According to the results, all the variables are significant in 5\% except one variable, value lagged. The value lagged is not significant and it signs the word of mouth (WOM) has no impact on repeat visitation, therefore not explaining the dependent variable. Hence it has removed from the model, and again run the GLS model to get the coefficient estimations on variables and results indicated in table 4.

Table 4. Results of the GLS Model Estimations (after remove lagged variable)

\section{Determinants of Tourism Competitiveness of Sri Lanka with Rival Destinations}

\section{Cross-sectional time-series FGLS regression}

Coefficients: generalized least squares

Panels: heteroskedastic with cross-sectional correlation

Correlation: common AR(1)

coefficient for all panels $(-0.0920)$

Estimated covariances $=28$

Number of obs $=56$

Estimated autocorrelations $=1$

Number of groups $=7$

Estimated coefficients $=5$

Time periods $=8$

Wald chi2(4) $=36.73$

Prob $>$ chi $2=0.0000$

\begin{tabular}{ccccccc}
\hline VALUE & Coef. & Std. Err. & $\mathbf{z}$ & $\mathbf{P}>|\mathbf{z}|$ & \multicolumn{2}{c}{$[\mathbf{9 5 \%}$ Conf. Interval] } \\
\hline & & & & & & \\
ARRIVALS | & $-1.49 \mathrm{e}-07$ & $3.34 \mathrm{e}-08$ & -4.47 & 0.000 & $-2.14 \mathrm{e}-07$ & $-8.37 \mathrm{e}-08$ \\
PRICE | & 19.19275 & 4.021076 & 4.77 & 0.000 & 11.31159 & 27.07392 \\
dlinv | & -28.97054 & 7.464689 & -3.88 & 0.000 & -43.60106 & -14.34001 \\
dlgdp | & 7.770424 & 2.452155 & 3.17 & 0.002 & 2.964289 & 12.57656 \\
cons | & 4.346094 & .9230052 & 4.71 & 0.000 & 2.537037 & 6.155151 \\
\hline
\end{tabular}

- $\quad$ dependent variable $=($ value $)$ rate difference in real tourist spending per tourist

\section{Discussion}

According to the results after removal of lagged value, all the variables, i.e. tourists' arrivals, technology (development), investment level and price are significant. All the variables demonstrated the direction expected, except investment. The development / GDP per capita is positive and is significant implies that, created assets and the technology itself represent important determinants of the competition among region level and having positive effect. The price factor is also an important determinant on the competitiveness level on tourism and it's also in positive direction as demonstrating that, more expensive (high priced) tourism destinations seems more able to achieve higher shares of regional spending of tourism . Croes (2010) explain this as Kaldor paradox. The arrival factor turns as a negative, as in expected way and significant demonstrated that the number of tourists could jeopardize the tourism destination value. This explains as the arrivals are closely related with carrying capacity of tourism destinations, and it will decrease marginal utility and willingness of tourists to pay. The coefficient getting a very low impact in tourism value, as the coefficient is -0.000000149 explains even its negative, the impact is very low it's related with carrying capacity of destination and also decrease the marginal utility, but in a very low capacity. The variable investment denotes and unexpected direction as it could be a positive impact for a tourism destination herein. That may be the result of the proxy that has taken as to represent the tourism sector investments within a destination, as in previous study, Croes (2010) have taken number of tourists hotels of given destination as a proxy for investment. Due to the fact that unavailability of data, the service value added from GDP in all services including hospitality and tourism has chosen. results suggested it has significant and given a negative estimation for competitiveness, as here selected the service value added 
percentage of GDP combined both wholesale and retail trade (including restaurants and hotels), financial services, transportation, government, professional and personal services including the education.

The results also lead for two dynamic effects on destination competitiveness in 2 different modes; i.e., changing reputation levels that capture by the influence in previous year on spending behavior of the present year, and by creating a distinction between a long run equilibrium towards on competitiveness appearing that to move from the present position. In similar study that done by Croes (2010) for 9 Caribbean tourism small islands destinations, appeared it as in a negative impact that seemed tourists were not satisfied by the service provide from their destination, as no repeat visitation due to that. But in this study, as it turn out an insignificant factor signals the repeat visitations on word of mouth marketing has no significant impact on tourism destination. The final implications results have indicating in Table 5;

Table 5. Implication Results

\begin{tabular}{ll}
\hline Variable & Implication \\
\hline Arrivals & $\begin{array}{l}\text { Increase number of tourists to the destinations decreasing the marginal } \\
\text { utility, but very low impact provided }\end{array}$ \\
Price & $\begin{array}{l}\text { More expensive tourism destinations are more likely to obtain larger } \\
\text { share of tourism revenue to the region }\end{array}$ \\
Level of development & $\begin{array}{l}\text { Development level of a destination, including its created } \\
\text { assets/resources and technology development are important } \\
\text { determinants of tourism competitiveness }\end{array}$ \\
& $\begin{array}{l}\text { Service value added percentage from GDP is not an appropriate proxy } \\
\text { on investment determination, as to increase tourism value. Moreover } \\
\text { investment showed positive impacts in previous studies (Croes, 2010) } \\
\text { signaling a change in proxy as in hotel and restaurant capacity, spa } \\
\text { centers, clubs etc. more appropriate to represent investment level in a } \\
\text { destination. This variable provides a research direction to future } \\
\text { studies, as on determine the tourism investment level in a destination. }\end{array}$
\end{tabular}

Competitiveness is a much more effective concept as well as a tool from both theoretical and practical perspectives and it enabling to focus on the productivity (efficient allocation of inputs/resources) and satisfying the visitors on the visitation to particular destinations. It is also signals a vital role of the government and government level policies by enhancing the ability on overcoming distortions and enabling price to send signals to potential markets as with restoring price informative power of particular tourism destinations. The destinations could concern more on attracting their 'tourism product' by considering more to preferences and tastes of a tourists in a creative, innovative approach and consistent way as by adjusting and implementing strategies on that non-price competition. Following competitive strategies could be recommended;

- The importance of shifting management policies and strategies on real spending per arrival or tourism spending per tourist, rather for market share, revenue or arrivals as a performance indicator.

- Non-price competition is convinced as a smart strategy as more expensive tourism destinations tend to obtain a higher share of regional tourism.

- The national wealth or economic development of tourism destination is not created as by its own resources or by the factor endowments, but it is a created and well managed choice by the destination itself.

The tourism goods/services and experiences could concern as the ability of a tourism destination that connect demand-side value creation on tourist satisfaction and delightedness (marginal utility on given tourism 
destination) with supply-side resources and activities as natural and created attractions, services, hospitality, infrastructure development etc., as the main focus towards on providing 'memorable tourism experience' than rivals. Ultimately this increases the competition level of the destination by increasing the quality of life of its residents.

\section{Acknowledgements}

Author's acknowledgment for Prof. Wei Long, Deputy Dean, School of Economics, Wuhan University of Technology, China PR, and Dr. Bandula Jayathilaka, Rajarata University of Sri Lanka for the assistance provided.

\section{References}

Annual Statistical Report of Sri Lanka Tourism, Sri Lanka Tourism Development Authority. (2009).

Annual Statistical Report of Sri Lanka Tourism, Sri Lanka Tourism Development Authority. (2010).

Armenski, T., Gomezelj, D. O., Djurdjev, B., Deri, L., \& Aleksandra, D. (2011). Destination Competitiveness: A challenging Process for Serbia. Journal of Studies and Research In Human Geography, 5(1), 19-33.

Bobirca, A., \& Cristureanu, C. (2006). Competitiveness Assessment and growth opportunities of the Romanian tourism sector. The Romanian Economic Journal, 21.

Central Bank Report, CBSL Sri Lanka. (2010, 2011).

Cracolici, M. F., Nijkamp, P., \& Rietveld, P. (2006). Assessment of Tourist Competitiveness by analyzing Destination efficiency, Tinbergen Institute Discussion paper, TI 2006-09712.

Croes, R. (2010). Small Island tourism competitiveness: expanding your destination's slice of paradise. Invited main lecture of University of Netherlands Antilles, Rosen College of Hospitality Management, University of Central Florida.

Crouch, G. I., \& Ritchie, J. R. (1995). Destination competitiveness and the role of the tourism enterprise. Working paper, 95-19.

Crouch, G. I., \& Ritchie, J. R. (1999). Tourism, Competitiveness and Societal Prosperity. Journal of Business Research, 44(3), 137-152

Dwyer, L., \& Kim, C. (2003). Destination Competitiveness: A model and Determinants. Current Issues in Tourism.

Enright, M. J., \& Newton, J. (2005). Determinants of Tourism destination competitiveness in Asia Pacific: Comprehensiveness and Universality. Journal of Travel Research, 43, 339-350.

Fernando, I. N. (2013). Measuring Tourism Competitiveness using Shift-Share Analysis: New Paradigm to Way forward Tourism in Sri Lanka. International conference on Business and Information 2013, University of Kelaniya, Sri Lanka.

Fernando, I. N., \& Long, W. (2012). New conceptual model on cluster competitiveness: A new paradigm for Tourism? International Journal of Business and Management, 7(9).

Inman, C., Segura, G., Moreno, J., \& Prado, A. (2002). Tourism in El Salvador-The competitiveness Challenge, Working paper, CEN 621.

Kim, C., \& Dwyer, L. (2003). Destination Competitiveness and Bilateral Tourism flows between Australia and Korea. The Journal of Tourism Studies, 14(2), 55-67.

Nordin, S. (2003). Tourism Clustering and Innovation-path to Economic Growth and Development. European Tourism research Institute, U 2003, 14.

Omerzel, D. G. (2006). Competitiveness of Solvenia as a Tourist Destination. Managing Global Transitions, 4(2), 167-189.

Porter, M. E., \& Stern, S., (nd.). National Innovation capacity, 9211 document, Institute for strategy and competitiveness. Harvard Business School.

Porter, M. E. (1990). The Competitive Advantage of Nations. The Free Press.

Porter, M. E. (2001). Regions and the New Economies of Competition Global city-regions (pp. 139-157).

Ramanujam. (2005). Strategic direction for the Tourism Industry in Sri Lanka, Sri Lanka Development forum. Background papers, 95-105. 
Ritchie, J. R. B., \& Crouch, G. I. (2010). A model of destination Competituiveness/Sustanaibility: Brazilian Perspectives. Revista de Administracao Publica, RAP, Rio De Janeiro, 44(5), 1049-1066.

Walsh, M., Lynch, P., \& Harrington, D. (2010). A capability-based framework for Tourism Innovativeness, discussion paper.

Walsh, M., Lynch, P., \& Harrington, D. (2013). A proposed model of firm-level Innovativeness: the small tourism firm, The national development plan of Ireland 2007-2013. Tourism policy Review.

Wares, A. C., \& Hadley, S. J. (2008). The Cluster Approach to Economic Development. Technical Brief No.7 World Travel \& Tourism Competitiveness Report, 2011

Yuksel, A., \& Yuksel, F. (2000). The quest for quality and Competitiveness: A case of Turkish Tourism. Sheffield Hallam University.

\section{Copyrights}

Copyright for this article is retained by the author(s), with first publication rights granted to the journal.

This is an open-access article distributed under the terms and conditions of the Creative Commons Attribution license (http://creativecommons.org/licenses/by/3.0/). 